\title{
Günümüz Sinema Seyir Gündeminin Belirlenmesi
}

\author{
Burak Medin \\ doktor öğretim üyesi, erciyes üniversitesi iletişim fakültesi \\ radyo televizyon ve sinema bölümü \\ burakmedin@erciyes.edu.tr
}

\section{Abstract \\ Determination of Today's Cinema Viewing Agenda}

Within the cinema viewing culture, cinema viewing agenda emerges as an important research title. It is obvious that many factors play a role on the audience's choice of watching movies and determining their own cinema viewing agenda. The construction of the cinema viewing agenda changes due the applications and virtual spaces built by the developments in computer technology. One of the most important questions in this change and transformation is whether the audience is on the lookout for a more autonomous and spontaneous decision or on the axis of different dynamics. The main problem that this study focuses on is whether the cinema viewing agenda is on an impractical and repressive axis pushed from above or on an autonomous and more independent framework against the impractical film canons or other actors. It is aimed to understand and discuss which actors play a role in the audience's film watching preferences and which elements the audience prioritize more in determining the audience's viewing agenda. In this study, a questionnaire was prepared as a data collection instrument and these questions were directed to 50 people who were determined using the purposive sampling technique. In addition, in-depth interviews were conducted through semistructured questions with 15 digital natives. The data obtained from these

Bu makaleye referans vermek için: Medin, B. (2018). Günümüz Sinema Seyir Gündeminin Belirlenmesi, Galatasaray Üniversitesi İleti-ş-im Dergisi, 28, 43-62. DOI: 10.16878/ gsuilet.436018 
questions and interviews were discussed/categorized together and common themes were identified. As a result, all data were analyzed in the context of thematic analysis in order to understand how today's cinema viewing agenda has been determined.

keywords: cinema, viewing, spectator/audience, cinema viewing agenda

\section{Résumé}

\section{Les motivations actuelles qui sous-tendent le choix de film des spectateurs de cinéma}

La motivation actuelle des spectateurs de cinéma à propos de leurs choix de film est un domaine important de recherche. Surtout avec le développement de la technologie informatique, la motivation des spectateurs de cinéma à propos de leur choix de film a subi une évolution. La question principale sur laquelle cette étude est basée est la suivante: la motivation pour le choix de film, est-elle imposée par des facteurs extérieurs ou déterminée d'une manière autonome et indépendante? Dans cette étude qui vise à comprendre et discuter les facteurs qui jouent un rôle sur les choix de film des spectateurs de cinéma et les éléments importants qui déterminent de leur motivation actuelle à propos de leurs choix, un questionnaire a été préparé pour recueillir des données et 50 personnes ont été interrogées. De plus, par le biais des questions semistructurées, on a réalisé des entretiens avec 15 personnes sur la plateforme virtuelle. A partir des données recueillies de ces questionnaires et des entretiens, les thèmes communs ont été déterminés. En conclusion toutes les données ont été analysées afin de comprendre la motivation actuelle des spectateurs de cinéma à propos de leurs choix de film.

mots-clés : cinéma, spectateur, la motivation des spectateurs de cinéma à propos de leur choix de film 
Öz

Sinema seyir kültüründe seyir gündemi, önemli bir araştırma sahası ve başıı olarak karşımıza çıkar. Geçmişten günümüze özellikle bilgisayar teknolojisinde yaşanan gelişmelere bağlı gelişen uygulamalarla ve inşa edilen sanal uzamlarla birlikte sinema seyir gündeminin inşası da farklılaşmakta, değişip dönüşmektedir. Bu çalışmanın üzerinde durduğu temel sorunsal seyir gündeminin yukarıdan ve tahakküm edici bir eksende mi yoksa dayatmacı film kanonlarına ya da daha farklı eyleyenlere karşı daha özerk ve daha bağımsız bir çerçevede mi şekillendiğidir. İzleyicilerin film izleme tercihleri üzerinde hangi eyleyenlerin rol oynadığını ve izleyicinin seyir gündemlerini belirlemede hangi unsurlara daha çok önem verdiğini anlamayı ve tartışmayı amaçlayan bu çalışmada, öncelikle veri toplama tekniği olarak bir anket formu hazırlandı ve bu sorular 50 kişiye yöneltildi. Ayrıca yarı yapılandırıımış sorular bağlamında 15 dijital yerliyle derinlemesine görüşmeler gerçekleştirildi. Bu sorulardan ve görüşmelerden elde edilen veriler beraber ele alınarak/sınıflandırılarak ortak temalar belirlendi. Sonuç olarak tüm veriler günümüz sinema seyir gündeminin nasıl belirlendiğini anlamak adına analiz edildi.

anahtar kelimeler: sinema, seyir, seyirci/izleyici, sinema seyir gündemi 


\section{Giriş}

1940'lardan başlayarak gelişen izleyici çalışmalarının sinema bağlamında 1980 'lerden itibaren hızlandığı görülür. Fakat gündelik yaşam, sinema ve izleyici ilişkisi özellikle son dönemlerde üzerinde sıkça durulan araştırma sahalarından biri olarak karşımıza çıkar. Gündelik yaşam, sinema ve izleyici arasındaki çok boyutlu ve karmaşık ilişkiyi ele almak toplumsal, ekonomik, siyasal ve kültürel birtakım unsurların da anlaşılmasına olanak sağlar. Kent yaşamının ve sosyal hayatın ayrılmaz bir parçası olan sinemayı filmlerin ve yönetmenlerin de ötesine geçerek izleyici temelli bir bakış açısıyla anlamaya ve incelemeye çalışmak, araştırmacıya geniş kapsamlı verilere ulaşma imkânı tanır.

Bu alanda yapılan literatür taraması sonunda özellikle son yıllar içinde üretilen film seyir deneyimi, film izleme alışkanlıkları ve pratikleri, sinema üzerinden izleyici çalışmaları gibi konulardaki çalışmalara sıklıkla rastlanır. Hem son zamanlarda hem de daha evvel üretilen ve alana katkı niteliği taşıyan ilgili çalışmalar kısaca şu şekilde sıralanabilir ve açıklanabilir. Medin (2018) "Dijital Kültür, Dijital Yerliler ve Günümüzdeki Yeni Film Seyir Deneyimleri" adlı çalışmasında 2000'li yıllardan günümüze yeni film seyir deneyimlerini dijital kültür temelli bir bakışla anlamaya çalışır. Medin'e göre dijital kültür bir dildir ve bu dil de günümüz seyir pratiklerini biçimlendirmede önemli bir rol üstlenmektedir. Dijitalleşen bu dil aynı zamanda bir iletişim mekânından da kopuk değildir. Bu bağlamda yazar çalışmasında dijitalleşen seyir kültürünü ve bu dilin film seyretme pratikleri üzerindeki etkisini dijital kültür ve mekân teorileri bağlamında ortaya koymaya çalışmaktadır. "Sinema Yeni Seyir Deneyimleri ve Çocuk İleyici" adlı çalışmada Özsoy (2017), Ingiliz Kültürel Çalışmalar geleneğinden yararlanarak sinemanın filmler vasıtasıyla seyircisiyle kurduğu ilişkiye odaklanır. Kentli çocuk izleyici özelinde günümüz sinema ve izleyici arasındaki ilişkiyi anlamayı ve tartışmayı amaçlar. Sözlü, yazııı ve elektronik kültür teorileri bağlamında değişen sinema seyir kültürünü "Değişen Sinema Seyir Kültürünü Sözlü, Yazılı ve Elektronik Kültür Bağlamında Anlamak" adlı çalışmasında ele alan Medin'e göre (2017) bu üç kültür arasındaki değişimler, geçişler ve karşıtlıklar sinema seyir kültürünü değiştirmektedir. Film izleme pratikleri bu kültürler bağlamında biçim kazanmaktadır. Bu kültürler ve bu kültürlerin ortaya çıkardığı dil ise bir seyir mekânından bağımsız değildir. Kültürün eklemlendiği iletişim mekânının bizatihi kendisi de hem kendi seyirci profilini oluşturmakta hem de seyrin biçimini şekillendirmektedir.

Yüksel'in ve Demir (2014) "2000 Kuşağının Sinema Filmleri İleme Pratikleri" adlı çalışmasında 2000 kuşağının film izleme pratiklerini ele alır, bu pratiklerden yola çıkarak sosyal ve kültürel değişimleri analiz etmeye çalışır. Ayrıca bu çalışmada değişen sinemanın temel üretim ve seyir formlarını da inceleyerek seyircinin konumunu ortaya koymaya çalışır. Okumuş (2014) "Sinema Tarihyazımı: Türk Sineması Tarihyazımı İçin Yöntem Arayışı" adlı çalışmasında sinema tarihyazımındaki değişimlere odaklanır, bu değişimlerden hareketle Türk sineması tarihyazımının kapsamını belirlemeye ve yeni bir sinema tarihyazım 
yöntemi önermeye çalışır. Okumuş'un çalışması doğrudan sinema, gündelik yaşam ve izleyici arasındaki ilişkiye odaklanmasa da Türk Sinema tarihyazımında eksik olan çalışma konularına dikkat çekmesi bağlamında önem taşır. Öztürk (2013) "Türkiye'de Sinema Mekânlarını Sözlü Tarih Üzerinden Anlamak" adlı çalışmasında, Akbulut ise (2014) "Sinemaya Gitmek ve Seyir: Bir Sözlü Tarih Çalışması" adlı çalışmasında 1960'lı ve 80'li yıllar arasında Türkiye'de sinemaya gitme deneyimini sözlü tarih üzerinden anlamaya çalışır. Kırel (2010) "Kültürel Çalışmalar ve Sinema" adlı çalışmasında sinemanın gündelik yaşamdaki yerine, seyircinin filmle kurmuş olduğu ilişkisine odaklanır. Bunun dışında film üretiminin ardında yatan temel oluşumlar, filmlerin nasıl ideolojik bir düzenleme oldukları ve kültür endüstrisi karşısındaki seyircinin konumu gibi çeşitli konuları ele alır. Erkılıç (2009) "Düş Şatolarından Çoklu Salonlara Değişen Seyir Kültürü ve Sinema" adlı çalışmasında, sinema salonlarındaki ve seyirci profilindeki değişimlere odaklanır. Ayrıca seyirci tercihleri de seyir kültürü bağlamında ele alınan bir başka konudur.

Corbett ve Wessels (2017) "Active audiences and reflexivity: How film audiences form in northern English regions" adlı çalışmasında Kuzey Ingiltere bölgesindeki izleyici profiline odaklanır. Temel olarak seyircinin nasıl şekillendiği sorusu üzerinde durur. Seyircinin şekillenirken filme ve film mekânlarına bağlandıklarını ileri sürer. "Exploring Art Film Audiences: A Marketing Analysis" (2009) adlı çalışmalarında Chuu, Chang ve Zaichkowsky, sanat filmi sevenlerin ticari film izleyicilerinden farklı film tüketim kalıplarına sahip olup olmadığı sorusunu inceler. Turner (2006) "Film As Social Practice" adlı çalışmasında filmi sosyal ve kültürel bir pratik olarak ele alır. Filmi kanonik bir metin olarak incelemek yerine eğlence, kültürel ve anlatı meselesi olarak inceler. Robert C. Allen'ın "Relocating American Film History: The Problem of the Emprical" adlı çalışması (2006) Kuhn'un çalışmasıyla benzerlik taşır. Allen, Amerika'daki ve diğer ülkelerdeki sinemaya gitme alışkanlıkları üzerine odaklanır. Kuhn "An Everyday Magic: Cinema and Cultural Memory" adlı çalışmasında (2002) etnik tarih yöntemiyle sinema tarihini ele alır. Psikolojik kuram da çalışmasında önem taşır. Sinemaya gitme alışkanlığının başlangıç yıllarına odaklanan Kuhn, kültürel hafızayı merkeze alır. Bu çalışmada 1930'ların Ingiltere'sinde sinemaya gitme alışkanlığı ve filmlerin izleyicileri nasıl etkilediği incelenirken sözlü tarih de kullanılan yöntemlerden biridir. Kuhn'un çalışmasında sinema tarihi, gündelik yaşamın izi sürülerek yazılmaya çalışıır. Seyircilerin iletişimsel bellekleri bu çalışmada önem taşır. Srinivas "The Active Audience: Spectatorship Social Relations and The Experience of Cinema in India" adlı seyir geleneği odaklı çalışmasında (2002), Hindistan'daki seyircinin sinemaya gitme alışkanlığını ele alır. Hindistan'daki sinema seyirciliğine odaklanarak seyircinin sinemayı algılayış biçimini ortaya koymaya çalışır. "Perverse Spectators: The Practices of Film Reception" adlı çalışmasında Staiger (2000), bir filmi metin olarak ele alır. Ona göre bir film toplumsal, politik ve tarihsel bir bağlam içinde ele alınmalıdır. Staiger'ın üzerinde durduğu bir diğer önemli konu ise anlamın izleyicinin filmle etkileşimi aracılığıyla ortaya çıkan bir sonuç olduğudur. Ona göre anlam, filme sabitlenen herhangi bir şey değildir. Stacey "Star Gazing: Hollywood Cinema and Female Spectatorship" 
(1994) adlı çalışmasında, televizyon izleyicilerinden hareketle kültürel çalışmalara gönderme yapar. Kültürel çalışmalardaki izleyici üzerine yapılan ampirik çalışmalarla feminist eleştirideki seyirci kuramlarını birleştirir. Kadınların filmlerle olan ilişkisini ele alır, onların sinemasal deneyimlerine odaklanır.

Görüldüğü üzere bu çalışmaların genel itibariyle film izleme pratiklerine, sinemaya gitme alışkanlığına, filmlerin izleyiciyi nasıl etkilediğine, sinema seyir mekânlarına, seyirci profiline ve bu profilin süreç içinde yaşadığı değişimlere, sinema tarihyazımı içindeki birtakım eksikliklere, sözlü, yazılı ve elektronik kültürün izleyiciye olan etkisine ve dijital kültür ekseninde dijital yerlilerin yeni seyir edimlerine odaklandığı görülmektedir. Bu çalışma ise yukarıda sayılan çalışmalarla sinema ve izleyici arasındaki ilişkiyi ele almak bağlamında benzerlik taşımakla birlikte farklı olarak günümüz sinema seyir gündeminin belirlenmesi sürecine ve bu sürece etki eden eyleyenlerin rollerine odaklanmaktadır.

Gündelik yaşam, sinema ve izleyici ilişkisi içinde "sinema seyir gündeminin belirlenmesi" süreci anlaşılması gereken önemli başlıklardan biri olarak karşımıza çıkar. Geçmişte olduğu gibi bu süreç günümüzde de farklı dinamikler ekseninde şekillenir. Televizyonun ve videonun devreye girmesiyle bir kırılma yaşayan sinema ve izleyici ilişkisi, yeni medya teknolojilerinin gündelik yaşama dâhil olmasıyla farklı bir boyut kazanır. Gelişen bu yeni iletişim teknolojileri hem seyir deneyimini hem de seyir gündeminin belirlenme sürecini dönüştürür. Bu teknolojilerin dolayımından geçen geleneksel izleyici, dijital izleyiciye dönüşmeye başlar. Seyrin ve seyredilenin kendisi kolektif bir biçimden, daha bireysel bir edime dönüşür. Seyir hem bireyselleşir hem de mahrem/özel alanlarda edimselleşir hale gelir.

Bu bağlamda, bu çalışmada yeni medya teknolojileri/dijital kültür ekseninde değişen ve dönüşen gündelik yaşamın içindeki izleyicinin/seyircinin sinema seyir gündemini nasıl belirlediğine, bu belirleme sürecine hangi unsurların etki ettiğine, izleyicilerin alternatif bir seyir gündeminin olup olmadığına, yeni iletişim teknolojilerinin bu gündem belirleme sürecindeki rolüne ve inşa ettiği olanaklara odaklanılmaktadır. Böylece 2000'ler sonrası sinema seyir gündeminin nasıl belirlendiği ortaya konulmaya çalışılmaktadır.

İzleyicilerin film belirleme tercihlerine hangi eyleyenlerin etki ettiğini ve izleyicilerin bu gündemlerini belirlerken hangi unsurlara daha çok önem verdiğini anlamak ve tartışmak amacıyla veri toplama tekniklerinden anket formu hazırlanarak amaçlı örneklem bağlamında 50 dijital yerliye yöneltildi. Anket formuyla izleyicilerin sinemaya gitme sıklığı ve film seçimini belirleyen unsurlar (film afişi, TV, film fragmanı, sosyal medya, radyo ve arkadaş) anlaşılmaya çalışıldı. Ayrıca yarı yapılandııımış sorular bağlamında 15 dijital yerliyle derinlemesine görüşmeler gerçekleştirildi. Bu görüşmelerle seyir gündeminin belirlenmesi sürecine yönelik daha detaylı verilere ulaşmak amaçlandı. 
Dijital yerli olarak tanımlanan hem anket hem de görüşme grubu için, birtakım demografik sınırlılıklara gidildi: farklı ekonomik ve sosyo-kültürel düzeye sahip, genel itibariyle lisans öğrencisi, 18-25 yaş aralığında değişkenlik gösteren anket için 50, görüşmeler için 15 dijital yerli. Anket yapılan 50 kişinin 28'i kadın 22 'si erkek, yarı yapılandırılmış sorularla yapılan derinlemesine görüşmede ise 15 kişinin 8'i erkek 7'si ise kadındır. Görüşme yapılacak grupları belirlemek adına hem kartopu örneklem yöntemi kullanılarak farkı kişilere ulaşıldı hem de maksimum çeşitlilik örneklemesi kullanılarak çeşitlilik arttırılmaya çalışıldı. Sonuç olarak hem anket hem de görüşme verileri beraber ele alındı, sınıflandırıldı ve böylece ortak temalar belirlendi. Tematik analize tabi tutulan bu veriler, 2000'ler sonrası sinema seyir gündemini anlamak adına analiz edildi.

\section{Sinema, seyir ve seyirci}

Bir filmi deneyimleyen, film izlemenin yanı sıra seyir mekânını sosyalleşebilmek, görünür olabilmek ya da statüsünü sergileyebilmek amacıyla kullanan, haz ilkesinden hareketle dolaysız haz almak amacıyla özdeşlik ilişkisini başlatan seyircidir. Bir filmin film olduğunun tanığı Kırel'in de vurguladığı üzere (2012, s. 14) temel anlamda seyircidir. Ona göre seyirci, bir filmin bakan ve gören tarafıdır. Bu bağlamda seyirci, bir filmin temel bileşenlerinden biri ve tamamlayıcı eyleyenidir. Benjamin de seyircinin temel bileşenlerden biri olmasına vurgu yaparak (2003, s. 267) sinema çerçevesinde yapılacak bir çalışmada seyircinin dışarıda bırakılmaması gerektiğinin altını çizer.

Lumière Kardeşler'in 1895 yılında Trenin Gara Girişi (L'Arrivée d'un train en gare de la Ciotat) adlı kısa filmiyle ilk/erken seyir deneyimi başlar. Bu filmin deneyimlenmesiyle ilgili birçok kişiye dair iletişimsel bellek kayıtlarda sabittir. Örneğin Pezzella (2006, s. 39) bu filme dair seyir deneyimini ve insanların yaşadıkları korkuyu ve endişeyi şu sözlerle aktarır. "Lokomotif, kameranın bakışına doğru yaklaşır ve bu görüntü karşısında seyirciler trenin üzerlerine doğru geldiklerini düşünerek korku içinde kaçışır." Aynı filme dair diğer bir deneyim Ercüment Ekrem Talu'ya aittir (Scognamillo, 2014, s. 14). Sigmund Weingberg'in 1896-1897 yıllarında İstanbul'da Galatasaray'daki Sponek Birahanesi'nin salonunda gerçekleştirdiği ilk gösterimlere Talu'da katılır. Talu'nun Trenin Gara Girişi adlı film üzerine yaşadığı sinemasal deneyimine Tilgen'in yazılarından ulaşmak mümkündür (1956).

1 Prensky (2001a, 2001b) dijital yerli ve dijital göçmen olmak üzere iki temel kavramsallaştırma yapar. Prensky insanları dijital teknolojilere olan yakınlığı ve uzaklığı, teknolojik yetenek ve yetkinliklerine göre dijital göçmen (dijital immigrants) ve dijital yerli (dijital natives) olmak üzere iki gruba ayırır. Dijital göçmenler yeni teknolojiyi kullanmayı öğrenebilirler; fakat yeni bir dil öğrenmeye çalışan insanlar gibi teknolojinin dilini öğrenmeye çalışırken kekelemekte, teknolojinin anadilini konuşan yerlilerin yanında bir göçmene dönüşebilmektedir. Prensky'e göre dijital yerliler; 1980 ve sonrasında doğan, bilgisayarların, internetin ve video oyunlarının dijital dilini ana dilleri gibi konuşanlardır. Dijital göçmenler ise 1980 öncesinde doğan, dijital dünyanın içine doğmamış olsa da yeni iletişim teknolojilerinden bir şekilde etkilenmiş ve bu teknolojiye uyum sağlamaya çalışanlardır. 


\begin{abstract}
"Avrupa'nın bir yerinde bir istasyon, bacasından fosur fosur kara dumanlar savuran bir lokomotif, peşinde takılı vagonlar duruyor. Rıhtım üzerinde telaşlı telaşlı insanlar gidip geliyor. Ama ne geliş gidiş. Hepsini sara nöbetine tutulmuş sanırsınız. Hareketler o kadar hızlı, ölçüsüz ve acayip ki. Tren kalktı, bittabi sessiz sedasız. Aman yarabbi. Üstümüze doğru geliyor. Zindan gibi salonun içinde kımıldamalar oldu. Trenin perdeden fırlayıp seyircileri çiğnemesinden korkanlar intiyaten yerlerini terk ettiler galiba. Hani ya ben de korkmadım değil; lakin merak galip gelip beni iskemleye mıhladı. Bereket versin ki tren çabuk geçti gitti".
\end{abstract}

Görüldüğü üzere ilk dönem seyir deneyimlerinde korku ve endişe hâkimdir. Fakat bu endişeli süreç, izleyicinin sinemasal dünyaya olan aşinalığıyla sona erer. Erken dönem sinema seyir deneyiminden günümüze seyirci üzerine yapılan tanımlamaların ve kavramsallaştırmaların genel itibariyle seyir deneyiminden ve seyir mekânından bağımsız yapılmadığı görülür. Örneğin Mayne tarafından seyirci kavramı (1993, s. 1), sinemaya giderek filmleri deneyimlemeyi ve filmler üzerinden üretilen sembolik anlamları seyir mekânında tüketmeyi içeren bir faaliyet olarak tanımlanır. Bu bağlamda sinemaya gitme ve bu iletişim mekânındaki deneyim, önemli bir olgu olarak karşımıza çıkar. Tabi ki bu noktada ritüel kavramı da önemlidir, çünkü özellikle erken sinema seyir döneminde sinemaya gitmenin kendisi bir ritüel olarak görülür. Filmin öncesi, arası ve sonrasıyla yapılan tüm faaliyetler bir ritüele tabidir. Seyre dâhil olan bu ritüelin, özellikle televizyonun ve bu iletişim teknolojisine eklemlenen videonun gündelik yaşama dâhil olmasıyla sona erdiği söylenebilir.

Sinemanın sosyal tarafı ile ilgili çalışmalar üreten Jarvie'nin deyişiyle (1993, s. 23) kent yaşamına eklemlenen sinema, sosyal bir kurumdur. Sinemaya gitmenin kendisi izleyiciyi sosyalleştirir ve diğerleriyle ortak bir paydada buluşma imkânı tanır. Gelişen iletişim teknolojileriyle birlikte insanların klasik bağlamda sinema salonlarında bir araya gelmeleri biçim değiştirir. Bu çerçevede sinemanın izleyicisine sağladığı sosyalleşme, bir araya gelme, görünür olabilme vb. imkânlar da değişip dönüşür. Sinema temelli bu iletişim kamusal alandan özel ve mahrem alanlara doğru bir kayma eğilimi gösterir.

Casetti (1998, s. 4), izleyici/seyirci kimliğinin erken dönemden bu yana sürekli değişim gösterdiği üzerinde durur. Ona göre farklı disiplinlerin devreye girmesiyle seyirci kavramı çok boyutlu bir yapıya dönüşür. Farklı disiplinlerin seyirciyi çok boyutlu bir yapıya dönüştürdügü açıktır. Fakat buradaki temel eyleyenlerden birinin -teknolojik determinizme kaymadan- gelişen iletişim teknolojileri olduğunu söylemek yerinde olacaktır. Çünkü gelişen iletişim teknolojilerinin dolayımından geçen seyir mekânları ve seyre imkân tanıyan araçlar, seyirciye çok farklı mekânlarda ve zamanda seyri edimselleştirebilme olanağı tanır. Seyir ve seyir mekânları dijitalleşir ve bireyselleşir.

Kentsel ve kamusal bir mekân olan sinema, günümüzde farklı biçimlerle varlığını devam ettirse de gündelik yaşam içinde sinemaya gitmek genel itibariyle önemli bir faaliyet olarak görülmez. Anlık kararlarla gidilen yüzeysel bir eğlence 
biçimi olarak değerlendirilir. Bu seyirci Erkılıç'ın da ifade ettiği gibi (2009, s. 157) genel anlamda "gezelim, yiyelim, alışveriş yapalım bu arada da filme gideriz diyen patlamış mısır seyircisi" dir. Bu bağlamda anlık kararlarla gidilen sinema için de geçmiş dönemden farklı olarak bir ritüelden söz etmek çok da mümkün değildir. Sinemasal ritüelin yanı sıra sosyalleşmek, bir araya gelmek, sinemasal haz almak, gündelik sorunlardan kaçmak, bilgilenmek vb. sinemaya gitme nedenleri de günümüzde biçim değiştirmeye devam eder. Bu formun dışında kalan seyirci profili ve bu profile ait seyir pratikleri de söz konusudur. Bu seyir pratiklerini tüketim katedrallerinden ${ }^{2}$ ziyade özellikle müstakil sinema seyir mekânlarında ve bu mekanlar içinde düzenlenen film festivallerinde görmek mümkündür.

Erken dönem sinema seyir deneyiminden günümüze seyrin bizatihi kendisi, seyir mekânları ve seyrin amacı değişip dönüşse de değişmeyen unsurlardan biri seyir deneyiminin başlayabilmesi için seyircinin seyir gündemini belirleme edimidir. Esasında gündem belirleme süreci de seyirci ve seyir deneyiminde olduğu gibi tarihsel bağlam içinde ve belirli etkiler ekseninde değişip dönüşse de seyir gündemi belirleme edimi bir filmin deneyimlenmesini başlatan başat unsurlardan biridir. Bu nedenle bu edimin hangi etkiler altında şekillendiği anlaşılmayı bekleyen önemli konulardan biridir. Bu bağlamda bu çalışma, elde edilen veriler çerçevesinde özellikle 2000'ler sonrası döneme odaklanarak günümüz sinema seyir gündeminin belirlenmesi sürecini anlamaya çalışmaktadır.

\section{Günümüz sinema seyir gündeminin belirlenmesi: Bulgular ve yorumlar} verileri

\section{Sinemaya gitme sıklığı ve film seçimini belirleyen unsurlar: Anket}

Bu çalışmanın veri toplama tekniklerinden ilki ankettir. Anket 22'si erkek 28 'i kadın olmak üzere toplamda 50 kişiye yöneltilmiştir. Anket sorularıyla kişilerin

2 Ritzer (2000, s. 26-27) alışveriş merkezlerini, tüketim katedralleri olarak kavramsallaştııır. Harvey ise (2008, s. 205) bu iletişim mekanlarını dejenere ütopyalar kavramı altında ele alır. Günümüzün büyük tüketim katedrallerinin temelinde (Ritzer, 2000, s. 107) öngörülebilirlik, hesaplanabilirlik, verimlilik ve insanın yerini teknolojinin alması gibi unsurlar yer almaktadır. Tüm bu denetim mekanizmaları esasında akılcılaştırmanın unsurlarını meydana getirir. Bu mekânlarda tesadüfiliğe ve sürprizlere yer verilmez. Standartlaşma her yere sızmıştır. Örneğin hangi şehrin ya da hangi ülkenin fast food restoranına gidilirse gidilsin lezzet ve yemeklerin büyüklükleri aynıdır. Akılcılaşmanın bir diğer özelliği olan insansız teknoloji, bu tür mekânların artık her yerinde rol üstlenmektedir. Örneğin yürüyen merdivenler, bankamatikler, yol gösteren dokunmatik ekranlar, para karşılığı yemek ya da içecek veren makineler gibi. Makinelerin dili tüketim katedrallerinin her yerine sızmaya başlamıştır. Bu dil son derece monolojik bir etkileşim sunar. Bu da hayatın bizatihi kendisinin diyalojik değil monolojik bir biçime dönüşmesine neden olur. Böylece temassızlık temelli bir düzen inşa edilmeye başlamıştır. Tüm bu akılcılaştırma yöntemlerine karşın bu iletişim mekânlarının tekrar büyülenmesine intiyaç vardır; çünkü sadece akılıılaştırma pratikleri, insanların o mekânlarla olan iletişimini kesintiye uğratabilir. Tüketim katedrallerindeki yeniden büyüleme çeşitli yollarla yapılır: ışıklar, gösterişli vitrinler, dekorasyon, zaman zaman bu mekânlara davet edilen ünlü yıldızlar, kimi zaman orkestralar vb. Tüm bu yeniden büyüleme ile tüketim katedralleri büyük bir gösterinin parçası haline dönüştürülür. 
sinemaya gitme sıklığı ve film seçimlerini hangi eyleyenlere göre belirlediği ölçülmeye çalışılmıştır.

Grafik 1. Ankete Katılım - Erkek ve Kadın

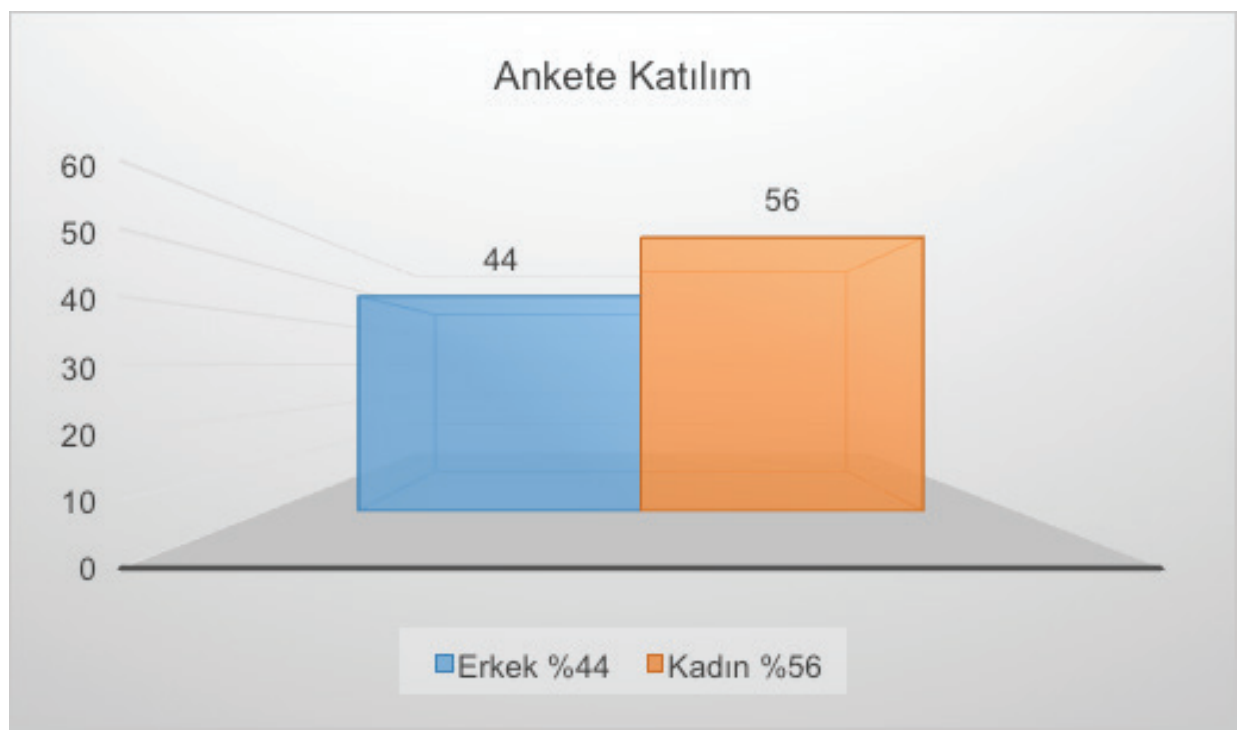

Erkek ve kadın katıımcıların ayrı birimler olarak değil birlikte değerlendirildiği anket sonuçlarına göre katıımcıların \%14'ü haftada bir kez, \% 2'si haftada birden fazla, \% 20'si ayda birden fazla, \% 38'i ayda bir ve \% 26'sı çok nadir sinemaya gitmektedir. Aşağıdaki çizelge erken seyir dönemlerinde televizyonun ve videonun olmadığı zamana dair bir yüzdeyi göstermiş olsaydı, tüm katılımcıların bir filmi ya sinema salonunda izlediği ya da izlemediği sonucuna varılabilirdi. Fakat anket içindeki bu soru bir filmi deneyimlemek için sinema salonuna gidilip gidilmediğini anlamak üzerine tasarlandı. Bir filmin sinema salonları dışında herhangi bir seyir mekânında ve herhangi bir zaman diliminde deneyimlenmesi sorulduğunda ise anket sonuçlarından hareketle yüzdelerin farklılık gösterdiği görülmüştür. Bu bağlamda bir filmi sinema salonu dışında başka bir seyir mekânında haftada bir kez deneyimleme oranı \%14'ten \%48'e çıkmıştır. Çok nadir olarak ifade edilen \%26'lık dilim ise yüzde 10'lara kadar gerilemiştir. Bu verilerden hareketle günümüzdeki film seyretme ediminin, kamusal alanlar içinde konumlanan sinema salonlarından ziyade diğer seyir mekânlarında daha fazla deneyimlendiği söylenebilir. 
Grafik 2. Sinemaya Gitme Sıklığı

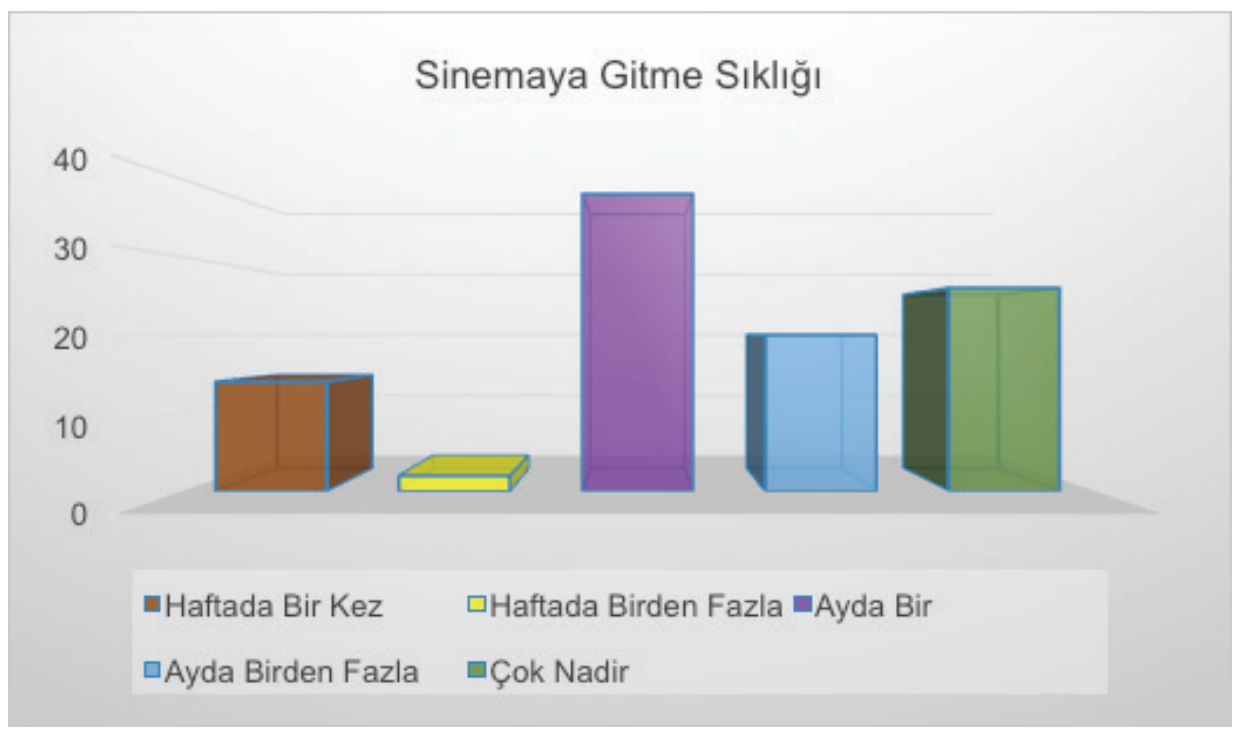

Anket sonuçlarına göre katılımcıların \%42'si film seçimlerini belirlerken film fragmanını, \% 40'ı ise sosyal medyayı dikkate alır. Geçmiş dönemlerde film seçimini belirleme noktasında kitleleri etkileyen en önemli iletişim araçlarından olan televizyonun ve radyonun bu seçimi belirlemedeki etkisi ise \%2'yi geçmez. Film fragmanının sinemada mı yoksa internet ortamında mı izlendiği sorusuna verilen cevap, oranlar ekseninde şu şekildedir: \%25 sinema salonları, \% 75 internet ortamı. Verilerden hareketle film afişi gibi hareketsiz imajlardan ziyade, günümüzde hareketli imajların daha çok ilgi gördüğü ve film seçimini doğrudan etkilediği ortadadır. Bu hareketli imajların sinema salonlarından ziyade, dijitalleşmenin de etkisiyle sanal uzama özellikle de sosyal medyaya kaydığı görülür. Sosyal medyada konumlanan ve takip edilen haber sitelerinde, sinemayla ilgili birtakım dergilerin sosyal medya uzantılarında ve buna benzer çoğaltabileceğimiz ekranlarda film fragmanlarını takip edebilmek ve filmlere dair bilgiler edinebilmek günümüzde daha kolaydır. Bu bağlamda film fragmanlarının izlenme oranının sanal uzama kaydığı düşünülürse film seçimini belirleyen başat etkileyici eyleyenin sosyal medya olduğu söylenebilir. 
Grafik 3. Film Seçimini Belirleyen Unsurlar

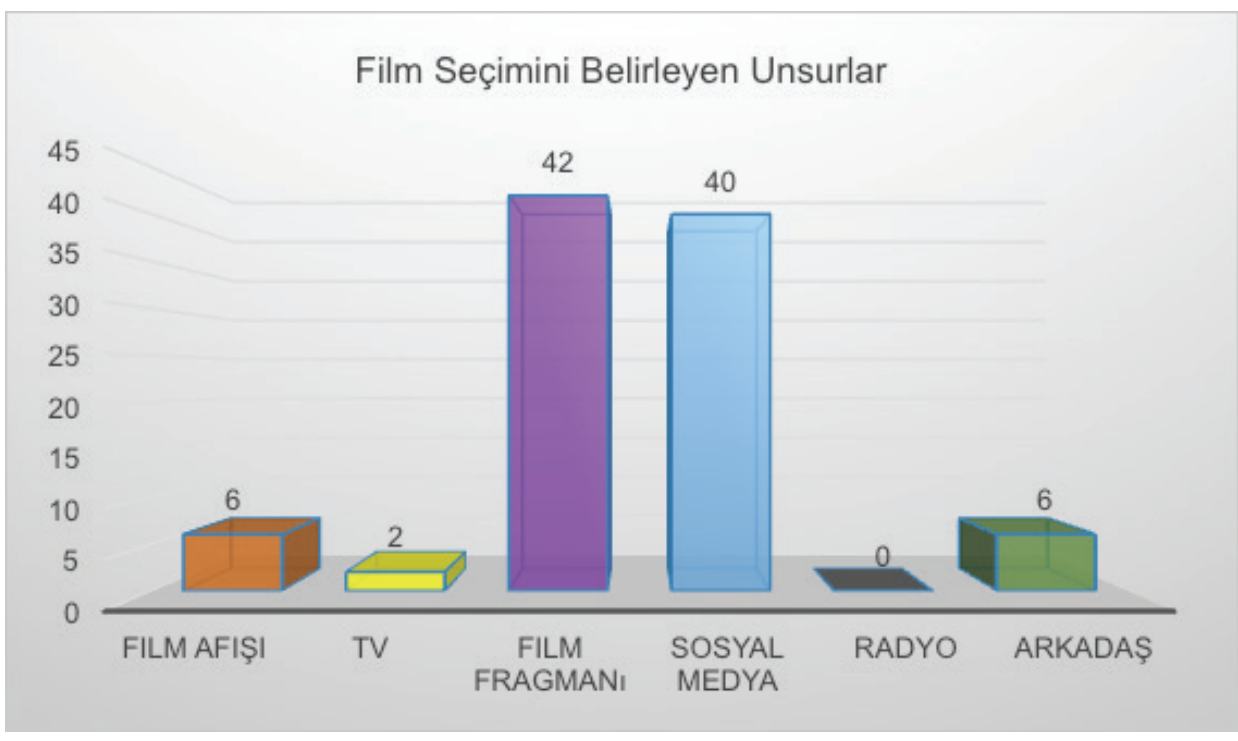

\section{Seyir gündeminin belirlenmesi: Derinlemesine görüşmelerden elde edilen veriler}

Tema 1. Seyir gündemlerinin belirlenmesinde sosyal medya önemli bir rol oynar. Bu bağlamda inşa edilen seyir gündemlerinin istisnalar dışında alternatif değil, çoğunluk tarafından kabul gören ve belirlenen bir gündem olduğu aşikârdır.

Yapılan derinlemesine görüşmelerden hareketle dijital yerlilerin sinema seyir gündemlerini belirlerken sosyal medya ortamından önemli oranda etkilendiği söylenebilir. Sanal uzamlarda film hakkında yapılan olumlu ya da olumsuz bir yorum viral bir etkiyle filme gitme kararı üzerinde belirleyici bir rol oynar. Gidilecek olan bir filmle ilgili sosyal medyada yapılan bir yorum, seyir mekânından filmle ilgili paylaşılan bir fotoğraf ya da konum bildirmek diğerlerinin seyir gündemlerini belirlemesinde rol alan önemli eyleyenlerdir. Bu bağlamda geçmiş dönemlerden farklı bir şekilde günümüzde bir filme gitmek, sadece bir filmi deneyimlemek değildir; sosyal medya aracılığıyla hem görünür olabilmek hem de diğerlerinin gündem belirleme süreçlerini etkilemektir.

Günümüzde filmlere http://www.imdb.com gibi sitelerde puanlar verilir, böylece film kanonları ${ }^{3}$ oluşturulur. Sinemayla ilgili neredeyse her

3 "Antik Yunan'da toplumsal kuralları belirlemede uygulanabilecek bir yasa, kanun ya da ilkenin koşullarını belirleyen ölçüt listesine de kanon adı verilir" (Okumuş, 2014, s. 45). Farklı türlerde kanonlar oluşturulmaktadır, bu durum sinema için de geçerlidir. "Tarihsel süreçte sanatsal 
internet sayfasında izlenilecek film listeleri hazırlanır. Bu filmik kanonlar listeler halinde insanlara sunulur, bu listelere göre seyir gündemleri belirlenir. Yapılan görüşmelerde bir filmin iyi ya da kötü bir puan alması, o film hakkında olumlu ya da olumsuz yorumlar ve birçok mecrada o film hakkında yapılan tanıtımlar, dijital yerlilerin film seçiminde önemli rol oynar.

Erkek 1: Fragmanları sosyal medyada çok görüyorsun. Hatta ilk buralara düşüyor diyebilirim. Arkadaşlar buralarda paylaşıyor. Kendi aramızda muhabbet konusu oluyor.

Kadın 2: Eğer arkadaş çevrem tarafımdan çok övülüyorsa izlemeyi tercih ediyorum.

Kadın 3: IMDB puanları yüksek olanları film listeme dâhil ediyorum. İşte izlenmesi gereken 100 film, ya da 250 film gibi listeler var. Sinema salonunun önünden geçerken bir filmin beni etkilemesi üzerine film izlediğim hiç olmadı. Fragman çok etkiliyor. Afişe bence bakılmıyor bile. Görsellik yok, filme dair detaylar yok. Arkadaş grubum film önerdiyse kesinlikle izliyorum. Bu önermeler illaki yüz yüze olmuyor, sosyal medyada tartışıyoruz. Buralarda filme dair her şey de hemen paylaşılıyor.

Erkek 4: Filmleri izledikten sonra WhatsApp'ta kurmuş olduğumuz bir grup var, uzakta olsak bile bu uygulama aracılığıyla filmi tartışıyoruz. Yeni önerilerimizi WhatsApp'tan da veriyoruz. Sevdiğimiz film kesitlerini telefondan çekip hemen WhatsApp'tan birbirimize gönderiyoruz. Bu uygulama da filme dair görselleri, fragmanları hemen paylaşmaya olanak tanıdığı için film belirlemelerimde önemli.

Kadın 5: Internetteki filmlerin afişlerine bakıyorum. Güzelse girip konusunu da okuyorum. Sonra bir de fragmana bakıyorum. Güzelse izliyorum. Sosyal medyada biri bir film paylaşıyor mesela. İlginizi çekiyor. Hiç izlemem dediğiniz bir türde bile olsa kendinizi izler buluyorsunuz. Sosyal medyadaki paylaşımlar çok etkili. Bu ortamlarda film üzerine çok söz söyleniyor. Siz de merak ediyorsunuz. IMDB puanlarını da tabi ki dikkate alıyorum. Bu listeler son derece belirleyici.

Kadın 6: Bütün sosyal medyada herkes Gri'nin Elli Tonu filmini konuşuyordu. Çok güzel bir film, kesin gidelim falan denildi. Afişine bakıyorsun, dikkat çekici bir afişi vardı. Ama beklediğim gibi çıkmadı film. Günümüzde bir film sosyal medyada ne kadar çok övülüyorsa o kadar iyiymiş gibi algılanıyor. Sosyal medya dışında bir filmin IMDB puanına da bakıyorum. Ya da sinemalar.com daki, ekşi sözlükteki yorumlara falan bakıyorum. Zaten izlenmesi gereken listeler vardır. Bu listeye göre film seçer, izlerim evde. Listelerdeki filmlerden ismi ilgimi çektiyse hemen seçer izlemeye başlarım.

değerleri göz önünde bulundurularak bir film dizgesi oluşturulduğu görülmektedir ki bu dizge film kanonunu meydana getirmektedir. Hangi filmler sorusuyla ilgili olan film kanonu en genel açıklamasıyla herhangi bir sanatsal özelliğiyle öne çıkarak eleştirilmeye, üzerinde konuşulmaya, örnek gösterilmeye değer bulunan filmlerin listelenmesidir. Film kanonları film eleştirisi yapılırken kuramsal sinema çalışmalarında ya da sinema tarihyazımlarında çeşitli amaçlarla kullanılmaktadır. Kanon içerisinde bazı filmler yer alırken diğerleri göz ardı edilir" (Okumuş, 2014, s. 78). "Kanon; eleştirmenler, kuramcılar, tarihçiler, akademisyenler, arşivciler, yapımcılar tarafından belirlenerek hangi filmleri izleriz/izlemeliyiz sorusuna yanıt verirler" (Altman, 1977, s. 24). 
Filmlerle ilgili tanıım günümüzde geçmiştekinden çok farkı bir şekilde yapılmaktadır. Sosyal medya ortamında filmle ilgili bilgiler edinilebildiği gibi, filmle ilgili çeşitli yorum yapma imkânı da vardır. Hatta bazı filmlerin nasıl olması gerektiğine yönelik izleyicilerin bilgisine başvurulmaktadır. Bu yorumların yanı sıra daha evvel ifade edildiği gibi filme dair fragmanlar, afişler ve kamera arkası görüntüleri de paylaşılabilmektedir. Bu bağlam içinde düşünüldüğünde sosyal medya ortamının seyir gündeminin belirlenmesinde birçok unsuru kendi bünyesinde barındıran önemli bir eyleyen olduğu söylenebilir. Yüz yüze yapılan sohbetler, filmin afişi ve herhangi bir medya ortamında karşılaşılan filmin fragmanı gibi eyleyenler de sosyal medyanın yanı sıra seyir gündeminin belirlenmesinde rol alan diğer önemli faktörlerdir. Bu eyleyenlerin dışında kişinin ilgi alanı da bu sürece etki eder. Fakat kişinin ilgi alanına göre bağımsız bir şekilde seyir gündemini inşa ettiğine yönelik bir görüş sorunlu görünmektedir. Kişi büyük bir endüstriyle karşı karşıya olduğundan yapı karşısında tam anlamıyla bir faillikten ve tam anlamıyla alternatif bir seyir gündeminden söz etmek bu bağlamda zordur.

Erkek 7: Film eleştirisi yapılan sayfaları takip ediyorum. Zaten bu bilgiler sosyal medya sayfamda görünüyor. Fragmanlarını izliyorum yine sosyal medya araciığıyla. Afişleri çok dikkate almıyorum; çünkü afişlerin hepsi birbirine çok benziyor günümüzde. Ama bilimkurguyla ilgiliyim. Bu nedenle afişinde bir robot ya da uzay resmi gördüğümde o filmle ilgileniyorum. Bu sefer de fragmana bakıyorum afiş tek başına etkili olmuyor.

Kadın 8: Filmlerin almış olduğu puanlar benim için çok önemli. Genellikle iyi puan almış filmleri izliyorum. Sosyal medya çok önemli benim için. Oradaki konuşmalar olumlu ve olumsuz bir şekilde film seçimimde etkili. Afişler eskisi gibi etkilemiyor artık. Onun yerine fragmana kesinlikle bakıyorum. Bir de düşüncelerini önemsediğim insanlar var. Film, kitap falan öneriyorlar. Onları kesinlikle izliyorum.

Erkek 9: Takip ettiğim yönetmenlerin işleri varsa ya da okuduğum kitaplar filme uyarlandıysa onlara gitmeyi tercih ediyorum. Çizgi roman karakterlerinin Iron Man, Batman gibi filmlerini takip ediyorum. Bunların dışında arkadaş ortamı tabi çok etkili oluyor. Aramızda konuştuğumuz filmlere de gidiyoruz. Filmin afişi etkilemiyor beni çok fazla. Afişe bakıp girdiğimi hatıllamıyorum. Ama internet sitelerinde filmlerin afişlerini koyuyorlar mesela. Hiç bilmediğim bir filmi bu şekilde online ortamda izlemiştim. Ama gerçek hayatta bu şekilde hiç izlemedim. Tabi bunda maddi durumlar etkili. Gerçek hayatta hiç bilmediğim filme gireceksem bu maddi bir risk bana göre. Hem de afişte bir belirsizlik var. Gerçek hayatta çarpıya basıp çıkamıyorsun kolay kolay, ama internet ortamında çarpıya basıp başka bir filme geçebiliyorum. Fragman ise çok etkiliyor. Film bașlamadan evvel izlettirilen fragmanlardan etkilenip filmlere giriyorum. Bazı filmler Twitter'da çok konuşuluyor mesela. İzlemediysen sende izleme ihtiyacı hissediyorsun. Her iki türlü aslında. Hem izleme hem de izlememe üzerinde sosyal medyanın önemli bir etkisi var. Twitter'da takip ettiğim film sayfaları var ayrıca. O sayfalara genellikle filmin afişleri ve fragmaları ekleniyor. YouTube'u da takip ederim. Abone oluyorum kanallara oradan fragmanlar paylaşılıyor. 
Kadın 10: Film listelerinden bir şekilde etkileniyoruz. Ama DVD'ler, internet falan nispeten bir özgürlük alanı var. Yasaklanan filmleri dahi internette bulabiliyorsunuz. Nihayetinde biz seçiyoruz filmleri. Ama bir yerde duymuş olmam gerekiyor filmi. Arkadaş çevresi önemli benim için. Kanaat önderi kişiler olmalı. Dergilerdeki yazarlara bakıyorum bir de sosyal medyada çok fazla konuşulmuş ise gidip izliyorum. Örneğin Interstellar filmi sosyal medyada çok fazla konuşulmuştu. Ben de merak edip izledim. Filmin afişi kısmen etkiliyor. Ama afişlerde çok fazla bir şey bulamıyorsunuz, filme dair daha fazla detay istiyor artık insanlar. Fragman daha tercihim. Görselliği daha rahat anlayabiliyorsun.

Günümüzde film seyretme deneyimi iletişim teknolojilerinde yaşanan gelişmelerle birlikte tek bir mekânda değil, çoklu mekânlarda yaşanır hale geldi. İzleyici taşınabilir ekranların getirdiği olanakların yanı sıra internetin getirdiği olanaklarla da istediği filmi istediği zaman izleme olanağına kavuştu. Bir seyir mekânında başlayan film seyretme deneyimi bu bağlamda çeşitlendi. Örneğin sinema salonunda film izlenildikten sonra sosyal medyada filmle ilgili görüşler paylaşılmakta, forumlarda filmle ilgili tartışmalar yürütülmekte, izlenilen film internette ya tekrar izlenilmekte ya da indirilerek seyir gündemi listesine dâhil edilmektedir. Dijital yerlilerden elde edilen verilerden hareketle film izleme deneyiminin çok boyutlu ve birçok unsurla ilişkili bir süreç olduğunu söylemek mümkündür.

Erkek 11: Sosyal medyada film bittikten sonra paylaşım yapıyorum. Arkadaşlarla bu ortamda bir kritik yapıyoruz. Sonra arkadaşlarla kendi aramızda yüz yüze bir muhabbet konusu oluyor. Filmi çok beğendiğim zaman eve gidip internette izlediğim ya da indirdiğim de oluyor. Filmin yorumlarına bakıyorum mesela. Eğer filmi beğendiysem benim için film salonda bitmiyor. Mesela arkadaşım sosyal medyadan soruyor, film nasıldı diye. Bende mutlaka gitmesini söylüyorum. Arkadaşım gittiğinde bu sefer onunla film hakkında konuşmaya başılıyoruz.

Üstten oluşturulan filmik kanonların izleyiciye sunulduğu, izleyicilerin de alternatif bir seyir gündemi oluşturmaktan ziyade bu listelere uyduğu dijital yerlilerle yapılan görüşmelerde gözlenmiştir. Görüşme anlatılarında görüldüğü üzere günümüzde seyir gündeminin inşasında birçok eyleyen önemli rol oynar. Bu eyleyenlerin önemli bir kısmı da yeni kamusal alanda yer alır: sosyal medya, sanal uzamdaki fragman ve afişler, YouTube gibi video siteleri, IMDB gibi film listeleri sunan siteler, WhatsApp gibi akıllı telefon uygulamaları.

Anlatılardan hareketle alternatif bir seyir gündeminin olmadığına yönelik genel bir yargıya karşın film festivalleri temelinde alternatif bir seyircinin ve seyir gündeminin varlığına yönelik görüşler de mevcuttur.

Kadın 12: Sinema kültür sitelerini takip ediyorum. Başka Sinema diye bir şey var. Oradaki filmleri izlemeyi tercih ediyorum ya da film festivallerini takip ediyorum. Buradaki filmleri, popüler filmlere tercih ediyorum. 
Film kanonlarına karşın film festivallerinde ya da "Başka Sinema" etkinliklerinde alternatif bir seyir gündeminin inşa edilmeye çalışılığı sıklıkla ifade edilir. Bu görüş sorunlu görünmektedir; çünkü film kanonları sadece egemen yapıyla ilişkili değildir. Alternatif olarak yorumlanan bu seyir mekânlarında da bazı filmler gösterilirken bazı filmler dışarıda kalmaktadır. Film festivallerinde ya da buna benzer oluşumlarda alternatif bir seyir gündemi sunmak amacıyla gösterime dâhil edilen filmler de belirli bir bakış açısının ürünüdür. Bu çerçevede bu film listelerinin ideoloji başta olmak üzere birtakım bağlamlar içinde oluşturulduğu söylenebilir. Bu nedenle bu seyir mekânlarındaki film listeleri ve seyir deneyimi alternatif bir seyir gündemi oluşturmaktan ziyade sanatsal film kanonları içinde değerlendirilmelidir. Sonuç olarak sanatsal olarak yorumlanan bu filmik kanonlar, yapısı gereği seyircinin seyir gündemini belirlemesinde son derece yönlendirici bir rol oynamaktadır.

\section{Tema 2. Filmik öğelerle ya da film kahramanlarıyla kurulan özdeşlik, sinema seyir gündeminin belirlenmesinde rol oynar.}

Günümüzde kitle kültürünün oluşumunda sinema, önemli bir rol üstlenir. Film kahramanları ve filmik öğelerle kurulan özdeşlik ilişkisi erken sinema seyir döneminden günümüze devam eder. Film kahramanlarının söylemleri, film kahramanlarının kıyafetleri ve konuşma biçimleri gündelik yaşamda zaman zaman yer bulabilir.

Erkek 13: Filmlerdeki karakterlerin kıyafetlerine bakıyorum. Ben de böyle yapmalıyım diyorum mesela. Oyuncunun şu mimiği çok iyiymiş, onu bende yapmalıyım diyorum zaman zaman. Konuşurken yapmaya çalışıyorum. Kurtlar Vadisi'nde Polat Alemdar gibi yürümek, onun paltosundan giymek çok olmuştur. Halen de vardır. Sevdiğim kahramanların filmlerini kolay kolay kaçırmam. Hatta ilk çıktığında sinema salonunda izlemeyi tercih ederim. Sinema salonunun görüntü kalitesi ve ses bakımından sevdiğim filmin ve oyuncunun hakkın vereceğini düşünürüm.

Kadın 5: Zaman zaman arkadaş ortamında filmlerden alıntılar yaptığımız oluyordu. Replik olarak özellikle. Giyimimi hiç etkilemedi ama bir şey anlatırken filmlerden beğendiğim sözleri kullandığım oluyor. Özellikle sosyal medyada bir filmdeki sözü alıp paylaştı̆̆ım çok olmuştur.

Erkek 14: Giyim kuşam olarak bence film ve film kahramanları belirleyici oluyor. Ekranda ne görüyorsak ona göre şekilleniyor tabi. Film kahramanlarını taklit eden arkadaşlarım var. Onun gibi yürüme, jest ve mimik açısından bir benzerlik.

Kadın 8: Sevdiğim filmlerin replikleri ağzıma çok dolanmıştır. Arkadaşlar arasında bu replikleri falan kullanıyoruz. Bir şeyi açıklamaya çalışırken filmlerin konularından ya da film repliklerinden yararlanıyoruz. Sosyal medyada falan alıntı yapılıyor çoğunlukla. İnsanlar kendilerini bu şekilde ifade ediyor. Kendim bir şeyler anlatmaktansa filmler üzerinden paylaşımlar yapmak daha açıklayıcı olabiliyor bence. 
Kadın 11: Filmlerden sonra bir iki gün örneğin Taşıyıcı filmindeki Jason Statham'ı örnek almıştım. Filmde kendi kendine kurallar uygulayan bir kahramandı. Sınırları vardı. Ben de onun gibi olayım dedim. Kurallarım ve sınırlarım olsun. Kadın olmama rağmen o beni çok etkilemişti. Cem Yılmaz'ın filmlerindeki esprileri falan çok kullanıyorum arkadaş ortamlarında. Sevdiğim oyuncuların filmlerini bu nedenle kaçırmamaya çalışırım.

Erkek 15: Mesela film izliyoruz, arkadaşımız sahnedeki bir şeyi beğeniyor ben şunu almak istiyorum deyip WhatsApp'tan bize gönderiyor. Bizde yorum yapıyoruz, al ya da alma diye. Film repliklerini falan ezberliyoruz. Giyimimize, sohbetimize çok yansıyor. Gündelik yaşamımda kendime Ryan Gosling'i örnek alıyorum. Onun vatandaş ve insan sevgisi beni etkiliyor. Ayrıca onun saçı gibi kestiriyorum. Bunun dışında Kenan İmirzalıoğlu'da beni etkiliyor. Onun kahramanlık filmleri beni heyecanlandırıyor. Onun gibi palto falan giydiğim oluyor tabi. Sosyal medyada onun sözlerini falan paylaşıyorum. Filmlerinden kareler koyuyorum. Insanlara anlatmak istediklerimi yaptığım bu paylaşımlar kısa bir sürede anlatabiliyor.

Film kahramanlarıyla ya da filmik öğelerle geçmiş dönemlerde kurulan özdeşliğin görünür kılındığı uzam, kamusal ya da özel alanlardı. İzleyiciler bu alanlarda filmlerden edindiklerini sunabiliyordu. Günümüzde ise filmlerle ve kahramanlarla kurulan özdeşlik, kamusal ya da özel alanların yanı sıra yeni kamusal alanlarda da sunulabilmektedir. Hatta yeni kamusal alanlardaki görünümün ve sunumun, diğer alanlara göre daha fazla olduğunu söylemek mümkündür. İzleyiciler film kahramanlarına dair sözleri ve etkilendikleri filmlerden küçük kesitleri sosyal medyada paylaşabilmektedir. Böylece benlik, bir vitrin olarak görülen yeni kamusal alanlarda filmik öğeler üzerinden inşa edilmeye çalışılmaktadır. Anlatılardan hareketle sinema seyir gündeminin, izleyicinin filmik öğelerle ve film kahramanlarıyla kurduğu özdeşlik ilişkisiyle de belirlendiğini söylemek mümkündür.

\section{Sonuç ve değerlendirme}

Gündelik yaşam içinde sinema, seyir ve seyirci ilişkisi araştırılması gereken önemli bir alan olarak karşımıza çıkar. Bu alanın alt başlıklarından biri de sinema seyir gündeminin belirlenmesi süreci ve bu sürece etki eden eyleyenlerin ne olduğudur. Film izleme tercihi üzerinde rol oynayan etkenlerin yanı sıra filmik kanonlara karşın alternatif seyir gündemlerinin var olup olmadığı da sorgulanan başlıklardan biridir. Bu süreci anlamak adına 2000'ler sonrası döneme odaklanan bu çalışma, dijital yerliler ekseninde birtakım verilere ulaşmaya çalıştı. İlk veri toplama tekniği olarak anket formu hazırlandı, daha detaylı verilere ulaşmak adına ise derinlemesine görüşmeler yapıldı. Sonuç olarak elde edilen veriler sınıflandırılarak seyir gündeminin belirlenmesi sürecine ışık tutulmaya çalışıldı.

Anket verileri göstermiştir ki film seyretme deneyimi kamusal alanlar içinde konumlanan sinema salonlarından ziyade özel ya da mahrem alanlarda yer alan seyir mekânlarında daha fazla oranla edimselleşmektedir. Anket verilerinden 
elde edilen bir diğer sonuç ise seyir gündemini belirleyen etkenlerin başında film fragmanının ve sosyal medyanın başı çektiğidir. Günümüzde hareketsiz/sabit imajlardan ziyade, dijitalleşmenin de etkisiyle hareketli imajların daha fazla ilgi gördügü açıktır. Fragman gibi hareketli imajlar özellikle sosyal medyaya eklemlenir oldu. Bir izleyici bir filme dair tüm unsurları sosyal medya başta olmak üzere sanal uzamda bulabilmektedir. Anket verilerinden hareketle sosyal medyanın ve sanal uzama eklemlenen her türlü içeriğin, sinema seyir gündeminin belirlenmesinde önemli rol oynadığı söylenebilir.

Dijital yerlilerle yapılan derinlemesine görüşmelerde de seyir gündeminin belirlenmesi sürecinde sosyal medyanın etkin rolü ortaya çıkar. Sanal uzamlarda film hakkında yapılan olumlu ya da olumsuz tüm yorumlar viral bir etki oluşturmakta, bu bağlamda izleyicinin filme gitme kararı da şekillenmektedir. Günümüzde bir filme gitmek, sadece bir filmi deneyimlemek değildir. Sinemaya gitmek sosyal medyayla ilişkilendirilerek görünür olabilmenin imkânını izleyiciye vermektedir. İzleyici, seyir mekânından konum bildirmekte, filme dair tartışma başlatabilmekte ya da diğerlerinin bu filme gidip gitmeme kararı üzerinde son derece etkili olabilmektedir.

Seyir gündeminin belirlenmesi sürecinde film kanonları devrededir. Film kanonları; hangi filmlere gidilmeli, hangi yönetmen sineması iyidir ya da hangi oyuncular daha yıldızdır sorusuna cevap veren listelerdir. IMDB gibi siteler kanonik film listelerinin yayınlandığı sanal uzamlardır. Yapılan görüşmelerde bu listelerin dijital yerlilerin film tercihleri üzerinde önemli bir etkisinin olduğu görülür. Üstten oluşturulan filmik kanonların izleyiciye sunulduğu, izleyicilerin de alternatif bir seyir gündemi oluşturmaktan ziyade genel itibariyle bu listelere uyduğu dijital yerlilerle yapılan görüşmelerde gözlenmiştir. Fakat bu kimi görüşlere göre alternatif seyir gündeminin tamamen olmadığı anlamına gelmez. Film festivallerinin ve bu bağlam içinde değerlendirilebilecek olan oluşumların alternatif bir seyir gündeminin inşa edilmesinde önemli bir rol oynadığı söylenmektedir. Bu görüş, görüşme anlatılarına da yansımıştır. Esasında bu görüş sorunlu görünmektedir. Çünkü sanatsal faaliyetler içinde de birtakım filmler izleme listesine dâhil edilmekte, kimileri ise bu listelerin dışında kalmaktadır. O sanatsal yapının ideolojik düşüncesi bu süreçte etkin bir rol oynamaktadır. Bu bağlamda ister egemen yapı içinde isterse de bu egemen yapının dışında gözüken birtakım sanatsal faaliyetler içinde film listeleri oluşturulsun, bunlar film kanonlarıdır. Film kanonları tahakküm edici ve yönlendirici bir yapıya sahiptir. Dolayısıyla alternatif bir seyir gündeminden ziyade birileri tarafından (egemen ya da sanatsal) tasarlanan listelere uyan bir seyirci profilinden bahsetmek daha doğru olacaktır.

Görüşmelerden hareketle filmik öğelerle ve film kahramanlarıyla kurulan özdeşlik ilişkisinin de seyir gündeminin belirlenmesi sürecinde etkin rol aldığı görülür. Bir kahramanla kurulan özdeşlik, izleyicinin o oyuncunun diğer filmlerini 
izlemesini beraberinde getirir. Kahramanla kurulan bu ilişki sonucunda o filme ve filmik öğelere karşı da bir yakınlık ilişkisi başlar. Görüşmelerde izleyicilerin takip ettikleri ve bekledikleri oyuncunun filmini kamusal alanlar içinde konumlanan alışveriş merkezlerindeki sinema salonlarında izleyerek sinemasal hazza eriştikleri bilgisine ulaşılmıştır. Görüşme anlatılarından hareketle bu durumun sinema salonlarının dış etkenleri dışarıda bırakacak denli büyük ekranlarından ve güdüleyici ses sistemlerinden kaynaklandığı söylenebilir. Bu bağlamda filmik öğelerle ve film kahramanıyla kurulan özdeşlik ilişkisinin seyir gündeminin yanı sıra seyir mekânının seçimini de etkilediği ortadadır.

Elde edilen veriler göstermektedir ki sinema seyir gündeminin belirlenmesi süreci tek boyutlu ve yüzeysel değildir. Aksine içinde birçok unsuru barındıran, yapıdan bağımsız olmayan ve yeni iletişim teknolojileriyle doğrudan ilişkili olan çok boyutlu bir süreç ve toplumsal bir edimdir.

\section{Kaynakça}

Akbulut, H. (2014). Sinemaya gitmek ve seyir: Bir sözlü tarih çalışması. Elektronik Mesleki Gelişim ve Araştırma Dergisi, 2 (Özel Sayı), 1-16.

Allen, R. C. (2006) Relocating American film history: The problem of the emprical. Cultural Studies, 20:1, 48-88.

Altman, C. F. (1977). Towards a historiography of American film. Cinema Journal, $16,1-25$.

Benjamin, W. (2003). The Work of Art in the Age of Its Technological Reproducibility. Cambridge: Harvard University.

Casetti, F. (1998). Inside the gaze: The fiction film and its spectator. USA: Indiana University Press.

Corbett, S., Wessels, B. (2017). Active audiences and reflexivity: How film audiences form in northern English regions. Journal of Audience Reception Studies, Vol. 14, Issue 2, 63-79.

Erkılıç, H. (2009). Düş şatolarından çoklu salonlara değişen seyir kültürü ve sinema. Kebikeç, 27, 143-162.

Harvey, D. (2008). Umut mekânları. (Z. Gambetti, Çev.). İstanbul: Metis Yayınları. Jarvie, I. C. (1993). Sosyal Bir Kurum Olarak Sinemaya Gitme. (Gülseren Güçhan, Çev.). 25. Kare, Sayı: 5, 22-25.

Kırel, S. (2010). Kültürel çalışmalar ve sinema. İstanbul: Kırmızı Kedi Yayınları.

Kırel, S. (2005). Yeşilçam öykü sineması. İstanbul: Babil Yayınları.

Kuhn, A. (2002). An everyday magic: Cinema and cultural memory. London, NY: I.B. Tauris. 
Chuu, S., Chang, J., Zaichkowsky, J. (2009). Exploring Art Film Audiences: A Marketing Analysis. Journal of Promotion Management, 15, 212-228.

Mayne, J. (1993). Cinema and spectatorship. London, New York: Routledge.

Medin, B. (2018). Dijital kültür, dijital yerliler ve günümüzdeki yeni film seyir deneyimleri. Erciyes Illetişim Dergisi Akademia, Cilt 5, Sayı 3, 142-158.

Medin, B. (2017). Değişen Sinema Seyir Kültürünü Sözlü, Yazılı ve Elektronik Kültür Bağlamında Anlamak. Selçuk Iletişim, 10(1), 357-386.

Okumuş, F. (2014). Sinema tarih yazımı: Türk sineması tarihyazımı için yöntem arayışı. Ankara: Gece Kitaplığı.

Özsoy, A. (2017). Sinema, yeni seyir deneyimleri ve çocuk izleyici. TRT Akademi, Cilt 2, Sayı 4, 356-374.

Öztürk, S. (2013). Türkiye'de sinema mekânlarını sözlü tarih üzerinden anlamak. Milli Folklor, 98, 19-31.

Pezzella, M. (2006). Sinemada estetik. Ankara: Dost Kitabevi Yayınları.

Prensky, M. (2001a). Digital natives, digital Immigrants. On the Horizon, 9(5), 1-6.

Prensky, M. (2001b). Digital natives, digital Immigrants, part 2: Do they really think differently? On the Horizon, 9(6), 1-6.

Ritzer, G. (2000). Büyüsü bozulmuş dünyayı büyülemek. (Ş. Süer Kaya, Çev.). İstanbul: Ayrıntı.

Scognamillo, G. (2014). Türk Sineması Tarihi. Ankara: Kabalcı Yayıncılık.

Srinivas, L. (2002). The active audience: spectatorship, social relations and the experience of cinema in India. Media, Culture \& Society, Vol. 24: 155-173.

Stacey, J. (1994). Star Gazing: Holywood Cinema and Female Spectatoship. London and NY.: Routledge.

Staiger, J. (2000). Perverse Spectators: The Practices of Film Reception. New York: New York University Pres.

Tilgen, N. (1956). Bugüne kadar filmciliğimiz. Yeni Yıldız Dergisi.

Turner, G. (2006). Film as social practise. New York: Routledge.

Yüksel, A., Demir, B. (2014). 2000 Kuşağı'nın sinema filmleri izleme pratikleri. Elektronik Mesleki Gelişim ve Araştirma Dergisi, 2 (Özel Sayı), s. 31-54. 